\title{
Continuous raw skim milk processing by pulsed electric field at non-lethal temperature: effect on microbial inactivation and functional properties
}

\author{
Juliane FLOURY*, Noël GROSSET, Nadine LECONTE, Maryvonne PASCO, \\ Marie-Noëlle MADEC, Romain JEANTET \\ UMR 1253, Science et Technologie du Lait et de l'CEuf, Inra-Agrocampus Rennes, \\ 65 rue de Saint-Brieuc, 35042 Rennes Cedex, France
}

Received 31 January 2005 - Accepted 15 July 2005

\begin{abstract}
Pulsed electric field (PEF) is an emerging non-thermal processing technology used to inactivate microorganisms in liquid foods such as milk. The objective of this research was to study the effectiveness of continuous PEF equipment (square wave pulses) on total microorganisms of raw skim milk and on Salmonella enteritidis inactivation under moderate temperatures $\left(\mathrm{T}<50^{\circ} \mathrm{C}\right)$. Processing parameters (electric field and pulse width) were chosen as follows: $45 \mathrm{kV} \cdot \mathrm{cm}^{-1} / 500 \mathrm{~ns}$ and $55 \mathrm{kV} \cdot \mathrm{cm}^{-1} / 250 \mathrm{~ns}$, with increasing pulse frequencies from 40 to $120 \mathrm{~Hz}$, that corresponds to an energy input varying from range $0-100 \mathrm{~kJ} \cdot \mathrm{kg}^{-1}$. In these conditions, the effectiveness of PEF processing on microbial inactivation was very limited: $1.4-\log$ reduction of total microflora and S. enteritidis was the maximal inactivation ratio obtained. The effect of these PEF treatments on physicochemical and technological properties of the milk was also evaluated. These process conditions had an effect on proteinic components of milk such as casein micelles, since viscosity of PEF-treated milk decreased and coagulation properties were enhanced for high field levels $\left(45-55 \mathrm{kV} \cdot \mathrm{cm}^{-1}\right)$ with 2.1 to $3.5 \mu$ s cumulated treatment time and square waves. This study demonstrated that, contrary to numerous previous studies, PEF treatments had an impact on some food constituents.
\end{abstract}

milk stabilization / Salmonella enteritidis / pulsed electric field / cheese-making properties

摘要 - 高压脉冲电场处理对脱脂原料奶中微生物失活作用和原料乳性质的影响。高压脉冲 电场 (PEF) 是近年来出现的一种非热加工技术, 主要应用液态食品 (如牛奶等) 的杀菌。 本文研究了在中温 $\left(\mathrm{T}<50{ }^{\circ} \mathrm{C}\right)$ 条件下一种连续高压方波脉冲电场装置对脱脂原料奶的中细 菌总数和肠炎沙门氏菌的灭活效果。所选择的参数 (电场强度 / 脉冲宽度) 为 $45 \mathrm{kV} \cdot \mathrm{cm}^{-1}$ / $500 \mathrm{~ns}$ 和 $55 \mathrm{kV} \cdot \mathrm{cm}^{-1} / 250 \mathrm{~ns}$, 脉冲频率从 $40 \mathrm{~Hz}$ 增加 $120 \mathrm{~Hz}$, 应的能量输出的范围为 $0 \sim 100$ $\mathrm{kJ} \cdot \mathrm{kg}^{1}$ 。在上述条件下经高压脉冲电场处理的原料奶中微生物失活率是非常有限, 菌落总数 和肠炎沙门氏菌菌数最多只下降 1.4 个对数数量级。同时又研究了高压连续脉冲电场处理对 原料奶物理化学和加工特性的影响。结果表明, 高压脉冲电场处理对牛奶的蛋白质组成 (酪 蛋白胶束）也产生了影响, 表现在经高压脉冲电场处理后牛奶的黏度降低; 同时在高压方 波脉冲电场的高电场强度 $\left(45 \sim 55 \mathrm{kV} \cdot \mathrm{cm}^{-1}\right)$ 下累计作用时间达 $2.1 \sim 3.5 \mu \mathrm{s}$ 时牛奶的凝聚性 大大地提高。本研究结果证明经高压脉冲电场处理对食物的某些组成具有一定的影响, 这 一结论与前人的许多研究结果完全不同。

牛奶的稳定性 / 肠炎沙门氏菌 / 脉冲电场 /干酪加工特性

* Corresponding author (通讯作者): Juliane.Floury@agrocampus-rennes.fr 
Résumé - Traitement de lait écrémé cru par champs électriques pulsés à température non létale : efficacité au plan de la destruction microbienne et effet sur les propriétés fonctionnelles. La tendance actuelle de l'industrie alimentaire est de proposer des alternatives aux traitements thermiques de pasteurisation. Ces traitements alternatifs doivent être efficaces sur le plan de la destruction bactérienne, mais moins sévères au plan physico-chimique, afin de garantir la qualité hygiénique des aliments tout en préservant leurs qualités nutritionnelles, sensorielles et fonctionnelles. Les traitements par champs électriques pulsés (CEP) sont souvent reconnus dans la littérature comme un des procédés innovants capables de répondre à ces nouvelles exigences. L'objectif de cette étude était donc ici d'évaluer l'efficacité de traitements en continu par CEP (impulsions électriques rectangulaires) réalisés à température non létale $\left(\mathrm{T}<50^{\circ} \mathrm{C}\right)$ sur la destruction de la flore endogène et des coliformes du lait ainsi que sur du lait préalablement inoculé avec Salmonella enteritidis. Les paramètres de traitements choisis (champs électriques et largeur des impulsions) étaient les suivants : $55 \mathrm{kV} \cdot \mathrm{cm}^{-1} / 250 \mathrm{~ns}$ et $45 \mathrm{kV} \cdot \mathrm{cm}^{-1} / 500 \mathrm{~ns}$, avec des fréquences d'impulsion variant de 40 à $120 \mathrm{~Hz}$, ce qui se traduit par un apport d'énergie compris entre 0 et $100 \mathrm{~kJ} \cdot \mathrm{kg}^{-1}$. Dans ces conditions, l'efficacité des traitements est très limitée puisque au maximum 1,4 log de réduction microbienne a pu être atteint sur la flore endogène et $S$. enteritidis. Parallèlement, l'effet des traitements par champs électriques pulsés sur les principales caractéristiques physico-chimiques et techno-fonctionnelles du lait a été évalué. Un effet sur les composants protéiques tels que les micelles de caséine a été constaté suite aux traitements CEP les plus intenses $\left(45-55 \mathrm{kV} \cdot \mathrm{cm}^{-1}\right.$ pendant 2,1 à $\left.3,5 \mu \mathrm{s}\right)$ puisque la viscosité du lait était diminuée et ses aptitudes à la coagulation étaient améliorées. En conclusion, ces expériences ont permis de montrer que, contrairement à ce qui est classiquement reporté dans la littérature, les traitements par CEP ont un impact non nul sur des constituants tels que les micelles de caséine.

stabilisation du lait / Salmonella enteritidis / champ électrique pulsé / aptitude fromagère

\section{INTRODUCTION}

Pulsed electric field (PEF) is one of the most promising emerging technologies for the replacement of traditional thermal pasteurization among non-thermal processes, apart from microfiltration eventually combined with moderate heat treatment $[16,22,27]$. PEF treatment consists of the application of high-voltage pulses (typically $20-55 \mathrm{kV} \cdot \mathrm{cm}^{-1}$ ) to foods placed between two electrodes. With the application of electric fields as short-duration pulses, minimal ohmic heating is generated and the process remains non-thermal. With regards to the effect of PEF on microorganisms and enzymes of milk, some controversial results have been obtained [2, $3,5,11,12,19,22,25,26,28]$. Table I shows that in several cases, high levels of microbial inactivation have been achieved, between 3 - and 4.5-log reduction $[10,11$, $28]$. In other cases a very limited effect or no effect has been detected [5, 13]. Concerning the effect of the temperature on microbial inactivation effectiveness, numerous authors observed that increasing the inlet temperature from 22 to $50{ }^{\circ} \mathrm{C}$ increased the sensitivity of microorganisms to PEF treatment $[5,26,27]$. This increase in the rate of inactivation with increasing temperature may be due to the decrease in the electric breakdown potential of the cell membrane, as previously suggested by Coster [6]. Undoubtedly, it was due to a synergetic effect with a thermal inactivation with regards to the initial temperature and ohmic heating by those PEF treatments (Tab. I).

Performing PEF treatment on milk inoculated with one or more microorganisms is useful for determining the susceptibility of microorganisms to PEF treatment relative to these microorganisms, but it does not indicate the effectiveness of this process for milk with a naturally occurring microbial population. To date, only two research studies are available concerning PEF treatment of raw skim milk [25, 28]. The authors reported a maximum of $1-\log$ to $2-\log$ reduction of the total flora for PEF-treated raw skim milk depending on the inlet temperature, 25 or $50{ }^{\circ} \mathrm{C}$. The next logical step to determine the ability to stabilize milk by PEF is thus to conduct more inactivation studies on raw milk and to try to increase the 
Table I. Review of the effectiveness of high pulsed electric field treatment of milk on bacterial inactivation in function of processing parameters.

\begin{tabular}{|c|c|c|c|c|c|c|c|}
\hline \multirow[t]{2}{*}{ Media } & \multirow[t]{2}{*}{ Bacteria } & \multirow{2}{*}{$\begin{array}{l}\text { PEF treatment conditions } \\
\text { (E, nb, duration and shape of the } \\
\text { pulses, treatment time) }\end{array}$} & \multirow[t]{2}{*}{ Mode } & \multicolumn{2}{|c|}{$\begin{array}{c}\text { Temperature } \\
\left({ }^{\circ} \mathrm{C}\right)\end{array}$} & \multirow{2}{*}{$\begin{array}{c}\text { Decimal } \\
\text { reduction } \\
\text { number } \\
\left(\log \mathrm{N}_{0} / \mathrm{N}\right)\end{array}$} & \multirow[t]{2}{*}{ Ref } \\
\hline & & & & Inlet & Outlet & & \\
\hline SMUF* & Escherichia coli & $\begin{array}{l}36 \mathrm{kV} \cdot \mathrm{cm}^{-1} ; 64 \text { pulses, } 2 \mu \mathrm{s} / \\
\text { pulse; square waveform; } 100 \mu \mathrm{s}\end{array}$ & Batch & $\begin{array}{c}7 \\
20\end{array}$ & n.d.* & $\begin{array}{l}4 \\
5\end{array}$ & [23] \\
\hline \multirow{12}{*}{$\begin{array}{l}\text { Skim } \\
\text { milk }\end{array}$} & $\begin{array}{l}\text { Pseudomonas } \\
\text { fluorescens }\end{array}$ & $\begin{array}{c}15.5 \text { to } 22.4 \mathrm{kV} \cdot \mathrm{cm}^{-1} ; 15 \mu \mathrm{s} / \\
\text { pulse; waveform; } 30 \text { to } 130 \mu \mathrm{s}\end{array}$ & Batch & $\begin{array}{l}45 \\
50\end{array}$ & $\begin{array}{c}\text { estimated } \\
5.5^{\circ} \mathrm{C} / \text { pulse }\end{array}$ & $\begin{array}{l}0.2 \\
4.2\end{array}$ & [14] \\
\hline & Salmonella dublin & $\begin{array}{c}25 \mathrm{kV} \cdot \mathrm{cm}^{-1} ; 100 \text { pulses; n.d.; } \\
12 \text { to } 127 \mu \mathrm{s}\end{array}$ & $\begin{array}{l}\text { Conti- } \\
\text { nuous }\end{array}$ & $\begin{array}{l}30 \\
50\end{array}$ & n.d. & $\begin{array}{l}1 \\
2\end{array}$ & {$[27]$} \\
\hline & Total flora & $\begin{array}{l}\text { n.d. }(50 \mathrm{kV}) ; 50 \text { pulses; } \\
\text { waveform; n.d. }\end{array}$ & Batch & n.d. & n.d. & 2 & {$[25]$} \\
\hline & $\begin{array}{l}\text { Listeria } \\
\text { monocytogenes }\end{array}$ & $\begin{array}{c}25 \text { to } 35 \mathrm{kV} \cdot \mathrm{cm}^{-1} \text {; square } \\
\text { waveform; } 1.5 \mu \mathrm{s} / \text { pulse at } \\
1700 \mathrm{~Hz} ; 100 \text { to } 600 \mu \mathrm{s}\end{array}$ & $\begin{array}{l}\text { Conti- } \\
\text { nuous }\end{array}$ & $\begin{array}{l}25 \\
50\end{array}$ & n.d. & 0.5 to 1.5 & [26] \\
\hline & Listeria innocua & $\begin{array}{l}30 \text { to } 50 \mathrm{kV} \cdot \mathrm{cm}^{-1} ; 32 \text { waveform } \\
\text { pulses; } \cong 2 \mu \text { at } 3.5 \mathrm{~Hz}\end{array}$ & $\begin{array}{l}\text { Conti- } \\
\text { nuous }\end{array}$ & n.d. & 22 to 34 & 1.9 to 2.5 & {$[5]$} \\
\hline & $\begin{array}{l}\text { E. coli } \\
\text { L. innocua }\end{array}$ & $\begin{array}{c}41 \mathrm{kV} \cdot \mathrm{cm}^{-1} ; \text { n.d.; } 10 \text { to } 63 \\
\text { pulses of } 2.5 \mu \text { at } 3 \mathrm{~Hz}\end{array}$ & $\begin{array}{l}\text { Conti- } \\
\text { nuous }\end{array}$ & 17 & $\cong 37$ & $\begin{array}{l}2.3 \text { to } 4.5 \\
0.5 \text { to } 4\end{array}$ & [10] \\
\hline & P. fluorescens & $\begin{array}{c}50 \mathrm{kV} \cdot \mathrm{cm}^{-1} ; 50 \text { pulses, n.d.; } \\
2 \mu \mathrm{s} / \text { pulse; n.d. }\end{array}$ & Batch & n.d. & n.d. & 2.6 & [12] \\
\hline & Total flora & $\begin{array}{c}80 \mathrm{kV} \cdot \mathrm{cm}^{-1} ; 50 \text { pulses; } \\
\text { waveform; } 2 \mathrm{~s}\end{array}$ & Batch & 52 & n.d. & 1.3 & [28] \\
\hline & L. innocua & $\begin{array}{l}28 \text { to } 29 \mathrm{kV} \cdot \mathrm{cm}^{-1} ; 545 \mathrm{maxi} \\
16 \text { to } 32 \text { pulses at } 1.1 \text { or } 100 \mathrm{~Hz} \\
\quad \text { waveform; } 30 \text { to } 400 \mu \mathrm{s}\end{array}$ & Batch & 21.5 & $\begin{array}{l}\text { estimated } \\
25 \text { to } 45\end{array}$ & 0.2 to 1.5 & {$[22]$} \\
\hline & $\begin{array}{l}\text { P. fluorescens } \\
\text { Lactococcus lactis } \\
\text { Bacillus cereus } \\
\text { Total flora }\end{array}$ & $\begin{array}{c}35 \mathrm{kV} \cdot \mathrm{cm}^{-1} ; 64 \text { pulses; bipolar } \\
\text { square wave; } 47 \mu \mathrm{s} \text { ( } 1 \text { pass) } \\
\text { to } 188 \mu \text { s ( } 4 \text { passes) }\end{array}$ & $\begin{array}{l}\text { Conti- } \\
\text { nuous }\end{array}$ & 22 & 52 & $\begin{array}{c}1 \text { to } 4 \text { passes: } \\
0.5 \text { to } 2.2 \\
0.1 \text { to } 0.3 \\
0.6 \text { to } 3\end{array}$ & {$[21]$} \\
\hline & $\begin{array}{l}\text { Staphyloccocus } \\
\text { aureus }\end{array}$ & $\begin{array}{l}35 \mathrm{kV} \cdot \mathrm{cm}^{-1} ; 3.7 \mu \mathrm{s} / \text { pulse at } 250 \\
\mathrm{~Hz} ; \text { bipolar square wave; } 450 \mu \mathrm{s}\end{array}$ & $\begin{array}{l}\text { Conti- } \\
\text { nuous }\end{array}$ & 7 & $<40$ & 3.7 & [11] \\
\hline & L. monocytogenes & $\begin{array}{c}15 \text { to } 30 \mathrm{kV} \cdot \mathrm{cm}^{-1} ; 5 \text { to } 50 \text { pulses; } \\
\text { waveform; } 3.25 \mu \mathrm{s} / \text { pulse } \\
1 \text { pulse } / \mathrm{min}\end{array}$ & Batch & $\begin{array}{c}35 \\
0 \\
50 \\
55\end{array}$ & n.d. & $\begin{array}{c}0.03 \text { to } 0.87 \\
0.3( \pm 0.7) \\
1.5( \pm 1.0) \\
4.5( \pm 2.3)\end{array}$ & [13] \\
\hline $\begin{array}{c}2 \% \text { fat } \\
\text { milk }\end{array}$ & L. monocytogenes & $\begin{array}{c}25 \text { to } 35 \mathrm{kV} \cdot \mathrm{cm}^{-1} \text {; square } \\
\text { waveform; } 1.5 \mu \text { s/pulse at } \\
1700 \mathrm{~Hz} ; 100 \text { to } 600 \mu \mathrm{s}\end{array}$ & $\begin{array}{l}\text { Conti- } \\
\text { nuous }\end{array}$ & $\begin{array}{l}25 \\
50\end{array}$ & n.d & 1 to 2.5 & [26] \\
\hline & L. monocytogenes & $\begin{array}{c}25 \text { to } 35 \mathrm{kV} \cdot \mathrm{cm}^{-1} \text {; square } \\
\text { waveform; } 1.5 \mu \mathrm{s} / \text { pulse at } \\
1700 \mathrm{~Hz} ; 100 \text { to } 600 \mu \mathrm{s}\end{array}$ & $\begin{array}{l}\text { Conti- } \\
\text { nuous }\end{array}$ & $\begin{array}{l}25 \\
50\end{array}$ & n.d & 1.5 to 4 & [26] \\
\hline milk & L. innocua & $\begin{array}{c}28 \text { to } 29 \mathrm{kV} \cdot \mathrm{cm}^{-1} ; 545 \text { pulses } \\
\text { maxi; series of } 16 \text { to } 32 \text { pulses at } \\
1.1 \text { or } 100 \mathrm{~Hz} \text {; waveform; } \\
30 \text { to } 400 \mu \mathrm{s}\end{array}$ & Batch & 21.5 & $\begin{array}{l}\text { estimated } \\
25 \text { to } 45\end{array}$ & 0.2 to 2.5 & [22] \\
\hline
\end{tabular}

* SMF: model solution similar to milk ultrafiltrate; n.d.: not determined. 
level of microbial inactivation by combining this process with other treatments.

With regards to the effect of PEF treatments on functional properties, only a few studies are interested in the denaturation of milk components, in particular proteins and enzymes. Bendicho et al. [2] made quite a complete review of the existing literature about the effects of high-intensity pulsed electric field processing on milk enzymes. Controversial results have been reported, since great inactivation can be achieved for some enzymes under certain conditions; and no inactivation or even enhancement of the activity has been attained under different PEF conditions. Biochemical studies are needed to evaluate how PEF affects the internal configuration of the enzyme to decrease enzymatic activity. Concerning effects of PEF on protein-based food constituents and structures, Barsotti et al. [1] observed that electric exponential decay pulsed electric field processing did not cause significant protein unfolding or aggregation when tested on $\beta$-lactoglobulin or ovalbumin, two proteins known to be sensitive to heat or high pressure. The tetrameric enzyme lactate dehydrogenase was not inactivated after pulse processing. Electric pulses tended to dissociate large aggregates of fat globules in liquid dairy cream. However, the size distribution of fat globules in the studied emulsions was not markedly altered.

Finally, none of these studies take into account the process effect on food product functionality after treatment, though the industrial development of PEF greatly depends on this point. This bibliographic study also clearly revealed the difficulty of evaluating at the present time PEF processing effectiveness because in most studies, current and voltage are indicated but the delivered energy has not been calculated. This is mainly due to the quite strong heterogeneity of the procedures (batch or continuous mode), the incomplete characterization of the equipment and the absence of direct measurement of the process key factors (voltage, current, pulse width, outlet temperature, etc.). Moreover, the exponential decay pulses, most generally applied, are very difficult to describe by a "treatment time/electric field strength" combination, which limits the relevance of the correlations established between operating conditions and microbial inactivation. Considering this, a new concept of pulsed continuous electric field equipment has been developed. The spark gap switching technology used is designed to deliver square wave pulses with direct measurement and a great range of pulse duration, frequency and electric field strength [1].

The aim of the present study was to evaluate, with this equipment, the feasibility of pasteurizing milk by PEF. Experimental work was then to conduct more inactivation studies on raw milk by PEF, on its endogenous and pathogenic microflora, and also to measure the effect of this electrical processing on milk components and rennetability behavior.

\section{MATERIALS AND METHODS}

\subsection{PEF equipment}

The continuous PEF equipment developed (Fig. 1; Europulse, Cressensac, France) uses an original pressurized spark gap switching technology (dry air) with a high repetitive rate, connected to a pulseforming line consisting of a coaxial cable and lumped elements [17]. This equipment, including a $2-\mathrm{kW}$ high-voltage power supply charging capacitors and an interactive computer control (Labview software), generates square waveform pulses. It is designed to allow a widely adjustable operating pulse width (from 50 up to $3000 \mathrm{~ns}$ ), electric field strength (from 30 up to $80 \mathrm{kV} \cdot \mathrm{cm}^{-1}$ ) and pulse frequency (from 1 up to $815 \mathrm{~Hz}$ ), and to produce a volumetric flow rate (from 1 up to $\left.10 \mathrm{~L} \cdot \mathrm{h}^{-1}\right)$.

The square wave form of electric field pulses can be broken down into three parts: an increasing, a flat and a decreasing phase. Independently of the programmed pulse width, the increasing phase lasts about $20 \mathrm{~ns}$. The flat phase duration ranges from $50 \mathrm{~ns}$ to $3 \mu \mathrm{s}$. The decaying phase length increases from $30 \mathrm{~ns}$ to $500 \mathrm{~ns}$ for the programmed pulse width between $50 \mathrm{~ns}$ and $3 \mu$ s [18]. 


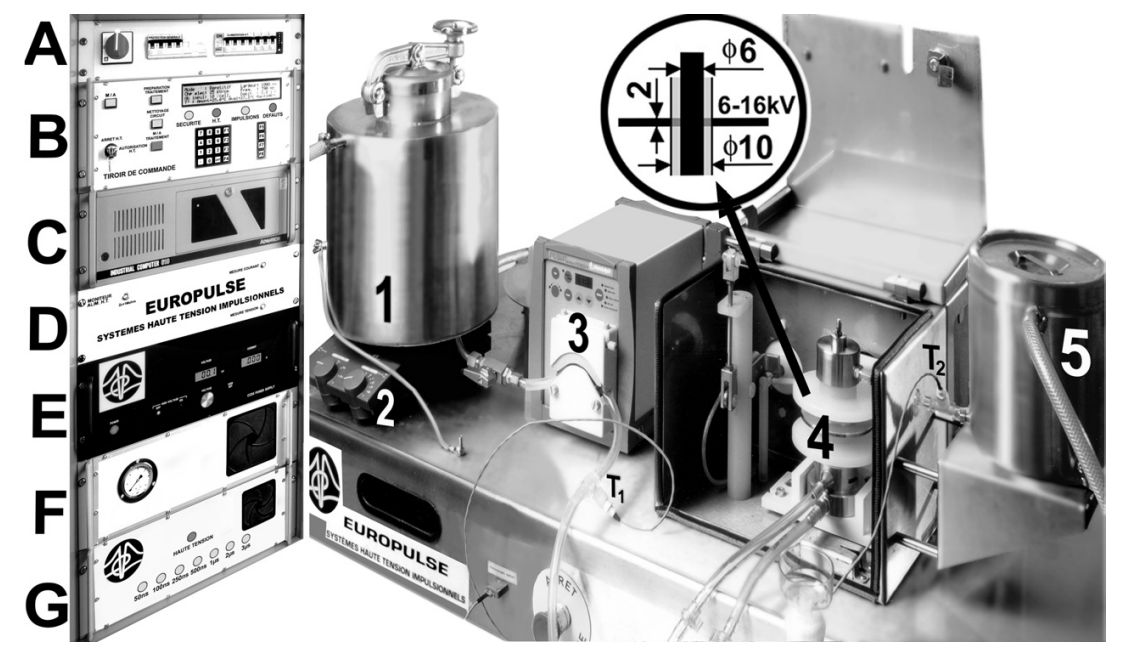

Figure 1. Equipment for continuous PEF treatment of liquid products.

Control panel: A: power supply; B: programing and control drawer; C: computer, D and E: high voltage monitor and power supply $(50 \mathrm{kV}, 2 \mathrm{~kW})$; F: spark gap switch $(0-815 \mathrm{~Hz})$; G: high voltage energy storage (50 ns, $100 \mathrm{~ns}, 250 \mathrm{~ns}, 500 \mathrm{~ns}, 1 \mu \mathrm{s}, 2 \mu \mathrm{s}$ and $3 \mu \mathrm{s})$.

Hydraulic line: 1: supply tank (12 L); 2: magnetic stirrer; 3: peristaltic pump (0-25 L·h $\left.\mathrm{h}^{-1}\right)$; 4: PEF treatment chamber; 5: tubular heat exchanger; $\mathrm{T}_{1}, \mathrm{~T}_{2}$ : thermocouples.

The coaxial continuous treatment chamber is composed of two electrodes separated by a gap of $2 \mathrm{~mm}$. The treatment chamber is equipped with a high voltage resistive and a current monitor for the direct measurement of applied voltage and current with a TDS 3012 digital oscilloscope (Tektronix, Beaverton, USA).

The hydraulic line includes a 12-L supply tank equipped with a cooling mantel and a variable speed peristaltic pump ( 0 to $\left.25 \mathrm{~L} \cdot \mathrm{h}^{-1}\right)$. The temperature rise due to ohmic heating is measured by two thermocouples placed immediately before and after the chamber. The outlet temperature after treatment is controlled by the computer: if it exceeds $50{ }^{\circ} \mathrm{C}$ the PEF treatment is automatically stopped. The cooling of the product immediately after treatment is provided by a tubular heat exchanger. A $20-\mathrm{kg}$ full load digital balance controlled by the process computer measures the flow rate of the product.

\subsection{Dairy products}

\subsubsection{Raw skim milk}

Raw whole bovine milk, obtained from a local dairy farm (Rennes, France), was skimmed at $50{ }^{\circ} \mathrm{C}$ with a small-scale cream separator (Elecrem S.A., Chatillon, France) and kept at $4{ }^{\circ} \mathrm{C}$, until PEF processing to test its effectiveness on endogenous flora. The initial total mesophilic flora and coliforms were enumerated to, respectively, around $10^{6} \mathrm{cfu} \cdot \mathrm{mL}^{-1}$ and $10^{5} \mathrm{cfu} \cdot \mathrm{mL}^{-1}$.

Sodium azide $(0.05 \% \mathrm{w} / \mathrm{v})$ was added to the samples of milk destined for physicochemical analysis to prevent microbial growth after PEF treatment.

\subsubsection{Bacterial removal of skim milk by cross-flow microfiltration}

For the PEF experiments concerning the inactivation of Salmonella enteritidis, part 
of the raw skim milk was microfiltered. Before microfiltration, the skim milk was preheated to $50{ }^{\circ} \mathrm{C}$. Then cross-flow microfiltration was used to eliminate bacteria. The membrane module in alumine Sterilox (Société des céramiques techniques, Tarbes, France) had 19 channels, each with an inner diameter of $4 \mathrm{~mm}$, and a total membrane area of $0.2 \mathrm{~m}^{2}$. The average nominal pore size was $1.4 \mu \mathrm{m}$ and the temperature was $50{ }^{\circ} \mathrm{C}$. Under these conditions almost all of the whey proteins and casein micelles pass through the membrane while $99.99 \%$ of bacteria are retained.

Using microfiltered skim milk allows a better control of its microbial composition. Before PEF processing, this microfiltered milk was then inoculated $\left(10^{7} \mathrm{cfu} \cdot \mathrm{mL}^{-1}\right)$ with Salmonella enteritidis.

\subsubsection{Milk ultrafiltrate}

Milk ultrafiltrate (UF) was prepared from fresh pasteurized milk on an $8-\mathrm{kg} \cdot \mathrm{mol}^{-1}$ TAMI membrane (Tami Industries, Nyons, France) and stored at $4{ }^{\circ} \mathrm{C}$ after sterilization on a $0.2-\mu \mathrm{m}$ sterile Nalgene membrane.

Electrical conductivities $\sigma\left(\mu \mathrm{S} \cdot \mathrm{cm}^{-1}\right)$ of the raw skim milk, the milk ultrafiltrate and the $28-\mathrm{mmol} \cdot \mathrm{L}^{-1}$ glucose sodium sulfate solution, as a function of the temperature, were measured with a $145 \mathrm{~A}+$ conductivity meter (Orion, Cambridge, USA). For the temperature range between 0 and $50{ }^{\circ} \mathrm{C}$ the electrical conductivity of these fluids can be characterized by a linear relation:

$\sigma\left(\mu \mathrm{S} \cdot \mathrm{cm}^{-1}\right)=2338( \pm 53)+118( \pm 4) \mathrm{T}$ ( $\mathrm{T}$ in ${ }^{\circ} \mathrm{C}$ ) with a $R^{2}$ value equal to 0.99 .

The treatment cell electric resistance, $\mathrm{R}$ (in $\Omega$ ), was calculated by equation (1):

$$
\mathrm{R}=\frac{1}{\mathrm{~F} \cdot \sigma} \cdot \frac{\ln \frac{\mathrm{r}_{2}}{\mathrm{r}_{1}}}{2 \cdot \pi \cdot \mathrm{e}}
$$

where $F=1.69$ is the field enhancement factor of the treatment chamber; $r_{2}=5 \times 10^{-3}$ $\mathrm{m}$ and $\mathrm{r}_{1}=3 \times 10^{-3} \mathrm{~m}$ are the radii of the outer and inner electrode, respectively; and $\mathrm{e}=2 \times 10^{-3} \mathrm{~m}$ is the electrode length.

The characteristic impedance of the high voltage device used is $50 \Omega$. However, it is difficult to match this value with the cell resistance, because of the ohmic heating of the product. As an example, the cell resistance decreases from $73 \Omega$ at $10{ }^{\circ} \mathrm{C}$ to $30 \Omega$ at $50{ }^{\circ} \mathrm{C}$

\subsection{PEF experiments}

PEF experiments were realized at a volumetric flow rate of $5 \mathrm{~L} \cdot \mathrm{h}^{-1}$ in a single mode at non-lethal temperature $\left(\mathrm{T}<50^{\circ} \mathrm{C}\right)$. For the experimental flow rate of $5 \mathrm{~L} \cdot \mathrm{h}^{-1}$, the average residence time of the liquid through the treatment cell is equal to $0.072 \mathrm{~s}$. Single PEF treatments (one pass of the product through the treatment chamber) were carried out according to the following protocol:

(1) The hydraulic line was first cleaned by pumping $0.2 \% \mathrm{NaOH}$ for $5 \mathrm{~min}$ at $25 \mathrm{~L} \cdot \mathrm{h}^{-1}$ and sanitized with a $0.1 \%$ chlorine solution for another $5 \mathrm{~min}$. It was then rinsed for $2 \mathrm{~min}$ with a sterile $28-\mathrm{mmol} \cdot \mathrm{L}^{-1}$ sodium sulfate solution.

(2) The beginning of the PEF treatment was applied to this sterile solution.

(3) Once electrical parameters were steady, the balance tank, filled with the inoculated model solution, was connected to the pump by means of a three-way valve. Samples of treated product were collected after $5 \mathrm{~min}$, in order to eliminate a volume three times that of the hydraulic line.

\subsection{Pulse characterization}

All the experiments carried out on skim milk used two couples of electric field/ pulse width, optimized from the conclusions of the study on PEF processing parameters' effect on Salmonella enteritidis inactivation in a model solution [18]:

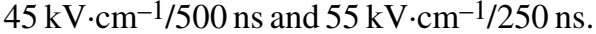
The overall amount of energy, $\mathrm{Q}$, delivered to the product during the PEF treatment $\left(\mathrm{kJ} \cdot \mathrm{kg}^{-1}\right)$ is calculated by the following equation:

$$
\mathrm{Q}=\frac{\mathrm{P} \cdot \mathrm{t}}{\mathrm{m}}=\frac{\mathrm{U} \cdot \mathrm{I} \cdot \mathrm{t}}{\mathrm{m}}=\frac{\mathrm{U}^{2} \cdot \mathrm{t}}{\mathrm{R} \cdot \mathrm{m}}
$$

where $\mathrm{P}$ is the applied electric power $(\mathrm{W})$, $\mathrm{t}$ the treatment time (s), $\mathrm{m}$ the amount of treated product $(\mathrm{kg})$, U the applied voltage (V), I the applied current (A) and R the electric 
resistance $(\Omega)$ of the treatment cell. It can also be underlined that the delivered energy can also be estimated by equation (3), considering as negligible heat loss through the metallic electrodes:

$$
\mathrm{Q}=\mathrm{m} \cdot \mathrm{Cp} \cdot\left(\mathrm{T}_{\text {outlet }}-\mathrm{T}_{\text {inlet }}\right)
$$

with Cp: specific heat $\left(\mathrm{J} \cdot \mathrm{kg}^{-1} \cdot \mathrm{K}^{-1}\right) ; \mathrm{T}_{\text {outlet }}$ and $\mathrm{T}_{\text {inlet }}$ the inlet and outlet temperatures $\left({ }^{\circ} \mathrm{C}\right)$ of the fluids measured by the two thermocouples (Fig. 1).

The electric field strength, $\mathrm{E}\left(\mathrm{V} \cdot \mathrm{cm}^{-1}\right)$, is calculated by equation (4):

$$
\mathrm{E}=\frac{\mathrm{U}}{\mathrm{d}}
$$

where $\mathrm{d}$ is the inter-electrode distance $(\mathrm{cm})$.

\subsection{Culture and enumeration of microorganisms}

\subsubsection{Escherichia coli and total flora}

The different microbial groups in raw skim milk samples before and after PEF treatment were enumerated as follows: total mesophilic flora on plate count agar (TSA, Biomerieux, Marcy l'Étoile, France) at $30{ }^{\circ} \mathrm{C}$ for $72 \mathrm{~h}$, and coliforms on violet red bile agar (CM107, Oxoid) at $30^{\circ} \mathrm{C}$ for $24 \mathrm{~h}$. After respective incubation, the colonyforming units (CFU) were counted.

\subsubsection{Salmonella enteretidis}

The strain of Salmonella enteritidis used in this study was a wild-type strain isolated from egg white (9066.94; Agence Française de Sécurité Sanitaire des Aliments, Paris, France) and conserved in cryobeads (AES Company, Combourg, France) at $-18{ }^{\circ} \mathrm{C}$. Before use, this strain was thawed and cultivated twice at $37^{\circ} \mathrm{C}$ for $24 \mathrm{~h}$ in Tryptic Soy Broth (TSB, Biomerieux, Marcy l'Étoile, France). Stationary phase cells were collected and washed with the glucose and sodium sulfate model solution (centrifugation $5000 \times g$ for $10 \mathrm{~min}$ at $20^{\circ} \mathrm{C}$, three times), and then inoculated at $2 \% \mathrm{v} / \mathrm{v}$ into the milk, obtaining a final inoculum of about $10^{7} \mathrm{~S}$. enteritidis cells $\cdot \mathrm{mL}^{-1}$.
Salmonella enumeration was carried out on the inoculated fluid before and after experimentation. Serial decimal dilutions in tryptone $\left(1 \mathrm{~g} \cdot \mathrm{L}^{-1}\right)$ - salt $\left(8.5 \mathrm{~g} \cdot \mathrm{L}^{-1}\right)$ water (TS, AES, Combourg, France) were prepared, and $1-\mathrm{mL}$ samples of each dilution were plated out in Tryptic Soy Agar (TSA, Biomerieux, Marcy l'Étoile, France). After incubation at $37^{\circ} \mathrm{C}$ for $24 \mathrm{~h}$, the colonyforming units (CFU) were counted.

\subsection{Physicochemical analysis}

\subsubsection{Separation of colloidal and soluble phases}

Immediately after PEF processing of raw skim milk, a 10-mL sample of milk was centrifuged at $20{ }^{\circ} \mathrm{C}$ for $60 \mathrm{~min}$ at $100000 \times g$ using a Sorvall (model Discovery 90SE) ultracentrifuge with a type T-865 rotor (Sorvall, Kendro Laboratory Products, Courtabœuf, France). The opalescent layer of fat globules at the top of the tubes was removed, and the supernatant or soluble phase was recovered with a syringe. The firm pellet considered as the colloidal phase is found at the bottom of the tube.

\subsubsection{Mineral partition}

Calcium concentrations were also determined in the milk samples immediately after PEF processing of raw skim milk, in order to measure the mineral partition before reaching equilibrium. Determination of the amounts of $\mathrm{Ca}$ in total milk and the soluble phase was performed in duplicate by atomic absorption spectroscopy (Varian SpectrAA 100 Series Atomic Absorption Spectrometer, Varian Australia Pty. Ltd, Victoria, Australia) according to the method described by [4].

\subsubsection{Viscosity}

Viscosity measurements of the raw skim milk after PEF processing were carried out at $25^{\circ} \mathrm{C}$ with a low shear viscometer (Contraves Low-shear 30 sinus, Contraves, Lamy, Caluire, France) with coaxial cylinders geometry $\left(\mathrm{r}_{1}=5.5 \mathrm{~mm} ; \mathrm{r}_{2}=6 \mathrm{~mm} ; \mathrm{h}=\right.$ $8.0 \mathrm{~mm}$ ). The shear rate range was 3 to $25 \mathrm{~s}^{-1}$. 
The behavior of the milk was Newtonian. Experiments were done in triplicate.

\subsubsection{Particle size measurement}

The evolution of the average size of casein micelles in raw skim milk samples with PEF treatments was evaluated at $25^{\circ} \mathrm{C}$ by photon correlation spectroscopy (PCS) on a Malvern Zetasizer 3000 HS (Malvern Instruments, Orsay, France), using a HeNe laser light $(\lambda=633 \mathrm{~nm})$ and a scattering angle of $90^{\circ}$. To replace micelles in their natural ionic environment, $2 \mu \mathrm{L}$ of milk sample, centrifuged beforehand $(3000 \times g$, $15 \mathrm{~min}, 25^{\circ} \mathrm{C}$ ) to remove all fatty globules, was diluted in $3 \mathrm{~mL}$ of milk ultrafiltrate. Samples were analyzed by the regularization method (CONTIN) to obtain information on particle size distributions. In a typical CONTIN output, the size distribution is divided into a series of size classes, and the percentage of the size distribution in each size class is calculated. The diameter of the particles was then calculated from the measured translational diffusion coefficient according to the Stokes-Einstein relation, by taking into account the values of viscosity $(0.89 \mathrm{mPa} \cdot \mathrm{s})$ and refractive index of the diluents $(\mathrm{RI}=1.33)$. All samples were assayed 10 times.

\subsubsection{Rennetability measurement}

The rennetability of PEF processed raw milk was measured on a Formagraph (Foss Electric, Paris, France). The instrument records a profile of growth of curd firmness as a function of time. The measured clotting process is influenced by milk, rennet and temperature. A typical diagram gives four parameters [20, 29]:

- R: time point at which the actual formation of gel commences ( $\mathrm{min}$ ),

- K20: time from the start of gel development until a width of $20 \mathrm{~mm}$ is reached (min),

- AR and A2R: widths at times of, respectively, two and three R ( $\mathrm{mm}$ ).

Before measurement, the $\mathrm{pH}$ of milk samples was checked ( $\mathrm{pH}$ was constant and equal to 6.7 for all samples) and equili-

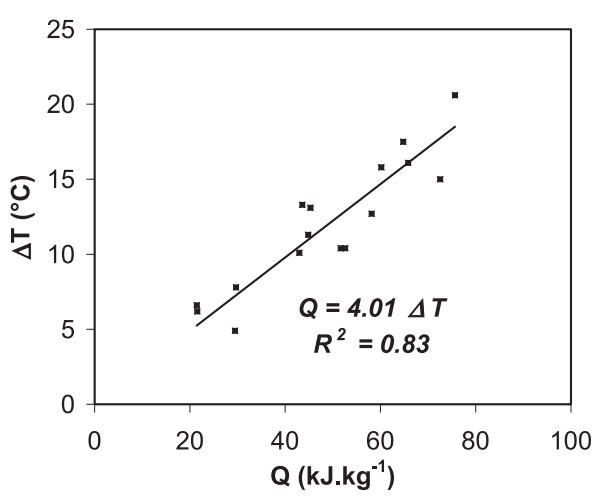

Figure 2. Relationship between the amount of energy ( $Q$ in $\mathrm{kJ}^{\circ} \mathrm{kg}^{-1}$ ) and the temperature increase $\left(\Delta \mathrm{T}\right.$ in $\left.{ }^{\circ} \mathrm{C}\right)$ during one passage of the product through the treatment cell.

brated for $12 \mathrm{~h}$ at ambient temperature to preserve mineral equilibrium, and for one hour before starting renneting measurements at $35^{\circ} \mathrm{C}$. Experiments were carried out at $35^{\circ} \mathrm{C}$ by adding to each milk sample $(10 \mathrm{~mL}) 100 \mu \mathrm{L}$ of a $1 / 20000$ aqueous rennet solution (Présure Berthelot, $530 \mathrm{mg} \cdot \mathrm{L}^{-1}$, Laboratoire ABIA, Meursault, France), with at least 3 repetitions at the same trials for each sample.

\subsection{Statistics}

Data were analyzed using the statistical analysis package Statgraphics Plus, version 5.1. (SigmaPlus, Levallois-Perret, France). Viscosity, average particle diameter and coagulation parameters data were analyzed using Student's $t$ statistics to determine if the averages of two sets of measurements were significantly different. In all cases, a $P$ value $<0.05$ was considered significant.

\section{RESULTS AND DISCUSSION}

\subsection{Product temperature}

As shown in Figure 2, the product temperature increases proportionally to the amount of energy delivered calculated from equation (2), due to ohmic heating, with an 
Table II. Example of some operating conditions and energy delivered to the raw skim milk product, $\mathrm{Q}\left(\mathrm{kJ} \cdot \mathrm{kg}^{-1}\right)$.

\begin{tabular}{|c|c|c|c|c|c|c|c|}
\hline \multirow[t]{2}{*}{ Frequency $(\mathrm{Hz})$} & \multirow[t]{2}{*}{$\mathrm{N}_{\mathrm{imp}}$} & \multirow{2}{*}{$\begin{array}{l}\text { Treatment } \\
\text { time }(\mathrm{ns})\end{array}$} & \multirow{2}{*}{$\begin{array}{l}\mathrm{T}_{\text {inlet }} \\
\left({ }^{\circ} \mathrm{C}\right)\end{array}$} & \multirow{2}{*}{$\begin{array}{l}\mathrm{T}_{\text {outlet }} \\
\left({ }^{\circ} \mathrm{C}\right)\end{array}$} & \multirow{2}{*}{$\begin{array}{l}\Delta \mathbf{T} \\
\left({ }^{\circ} \mathrm{C}\right)\end{array}$} & \multicolumn{2}{|c|}{$\mathrm{Q}\left(\mathrm{kJ} \cdot \mathrm{kg}^{-1}\right)$} \\
\hline & & & & & & Eq. (2) & Eq. (3) \\
\hline \multicolumn{8}{|c|}{$55 \mathrm{kV} \cdot \mathrm{cm}^{-1} / 250 \mathrm{~ns}$} \\
\hline 40 & 2.84 & 710 & 10.2 & 15.5 & 5.3 & 24.9 & 21.2 \\
\hline 80 & 5.7 & 1420 & 9.9 & 21.3 & 11.4 & 49.7 & 45.6 \\
\hline 100 & 7.1 & 1775 & 10.1 & 24.8 & 14.7 & 62.1 & 58.8 \\
\hline 120 & 8.52 & 2130 & 9.7 & 27.2 & 17.5 & 74.6 & 70.0 \\
\hline \multicolumn{8}{|c|}{$45 \mathrm{kV} \cdot \mathrm{cm}^{-1} / 500 \mathrm{~ns}$} \\
\hline 40 & 2.84 & 1420 & 11.2 & 18.3 & 7.1 & 33.3 & 28.4 \\
\hline 60 & 4.26 & 2130 & 11.8 & 22.5 & 10.7 & 49.8 & 42.8 \\
\hline 80 & 5.68 & 2840 & 12.0 & 26.0 & 14.0 & 66.9 & 56.0 \\
\hline 100 & 7.1 & 3550 & 12.2 & 29.7 & 17.5 & 82.0 & 70.0 \\
\hline
\end{tabular}

electric energy into heat conversion factor equal to $4.01 \mathrm{~kJ} \cdot \mathrm{kg}^{-1} \cdot \mathrm{K}^{-1}$, which approximately corresponds to the specific heat of milk.

With an inlet temperature lying between 10 and $20{ }^{\circ} \mathrm{C}$, the maximal amount of energy delivered to the product should not exceed $100 \mathrm{~kJ} \cdot \mathrm{kg}^{-1}$ in order to limit the temperature increase. This temperature increase was between 3 and $18^{\circ} \mathrm{C}$ max (Tab. II), which ensured PEF processing of milk at non-lethal temperatures for microorganisms.

\subsection{Bacterial inactivation}

Concerning the raw milk endogenous microflora, the inactivation ratios obtained were very variable between two different experiments, whatever the processing parameters applied (electrical fields, pulse width and cumulated treatment time). Furthermore, the maximal effectiveness of the PEF was very limited as the inactivation was between 0.2- and 1.4-log maximum reduction, even at the highest energy level, Q (Fig. 3).

A single pass of the product through the treatment chamber leads to energy input, according to the processing parameter values [17], within the range 0 to $100 \mathrm{~kJ} \cdot \mathrm{kg}^{-1}$. For these conditions, the relation between the amount of energy received by the fluid ( $\mathrm{Q}$ in $\mathrm{kJ} \cdot \mathrm{kg}^{-1}$ ) and the decimal reduction number $\left(\log \frac{\mathrm{N}_{0}}{\mathrm{~N}}\right)$ could be considered as linear (5):

$$
\log \frac{\mathrm{N}_{0}}{\mathrm{~N}}=\frac{\mathrm{Q}}{\mathrm{Q}_{\mathrm{D}}}
$$

where $\mathrm{N}_{0}$ and $\mathrm{N}$ are the number of viable microorganisms per gram before and after $\mathrm{PEF}$ treatment, respectively, and $\mathrm{Q}_{\mathrm{D}}$ is the decimal reduction energy (in $\mathrm{kJ} \cdot \mathrm{kg}^{-1}$ ). It is the energy required to obtain one decimal reduction of the considered bacterial population.

Inactivation ratios obtained in the present study were introduced in this relationship to determine the rough estimate of the decimal reduction energy, $Q_{D}$. $Q_{D}$ was about $100-120 \mathrm{~kJ} \cdot \mathrm{kg}^{-1}$, a value that was much higher than the decimal reduction energy of the $S$. enteritidis inoculated in the previous model solution [18]. $\mathrm{Q}_{\mathrm{D}}$ was equal to $40( \pm 2.9) \mathrm{kJ} \cdot \mathrm{kg}^{-1}$ in the solution composed of $28 \mathrm{mmol} \cdot \mathrm{L}^{-1}$ sodium sulphate and $28 \mathrm{mmol} \cdot \mathrm{L}^{-1}$ glucose.

To date, the only published research on PEF treatment of raw skim milk has been by [21, 25, 28]. Smith et al. [28] achieved only a 2-log reduction for PEF-treated raw skim milk. However, the electric field 
a) $T_{i n}=10^{\circ} \mathrm{C}$
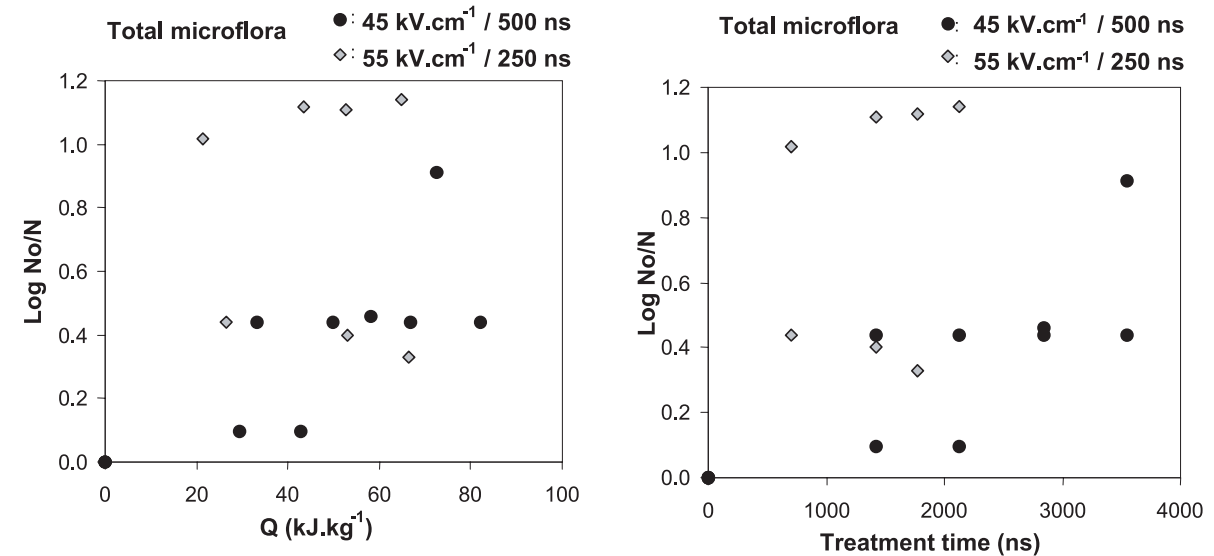

b) $T_{\text {in }}=10^{\circ} \mathrm{C}$
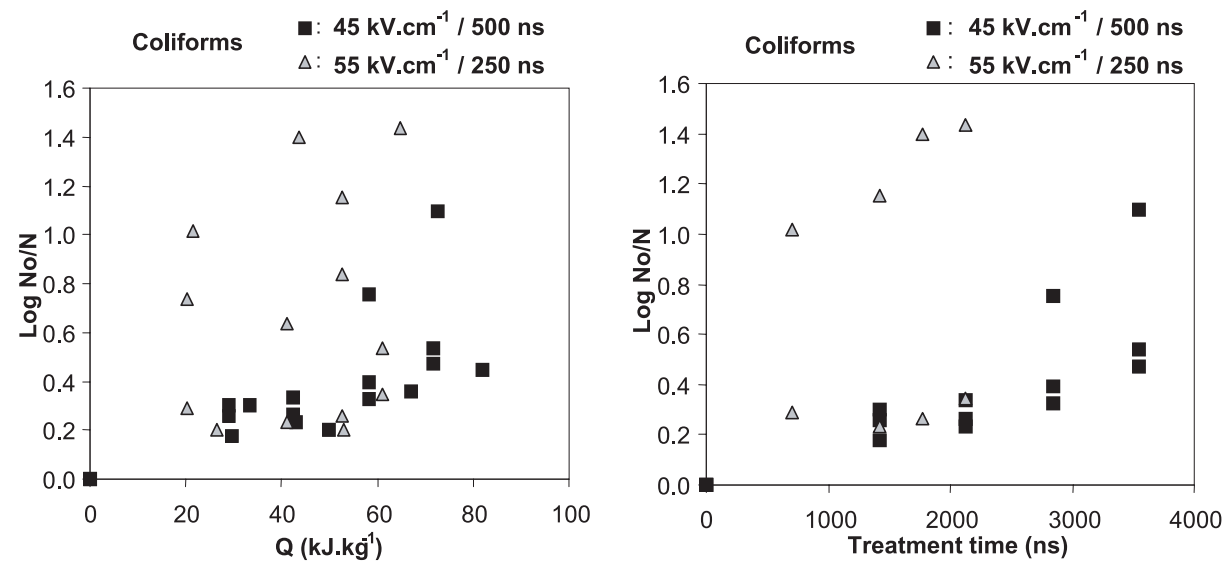

Figure 3. Decimal reduction number $\left(\log \mathrm{N}_{0} / \mathrm{N}\right.$ ) of endogenous microflora (a: Total microflora; $\mathrm{b}$ : Coliforms) of raw skim milk as a function of the amount of energy ( $\mathrm{Q}$ in kJ.kg-1) and the cumulated treatment time (ns) delivered to the sample during PEF treatment. $\mathrm{T}_{\text {inlet }}=10^{\circ} \mathrm{C}$.

strength and treatment temperature were not specified. Michalac et al. [21] obtained an overall $\log$ reduction of total microbial count in PEF-treated raw skim milk of 1.0$\log$ max. In this study, PEF processing parameters were chosen as follows: $35 \mathrm{kV} \cdot \mathrm{cm}^{-1}, 64$ pulses and cumulative treatment times varying from $47 \mu$ s (1 pass) to $188 \mathrm{~s}$ (4 passes).

This maximum of 1.0-log reduction of total microorganisms by PEF treatment in skim milk may be due to a combination of several factors, including PEF processing conditions $[16,17]$ and strong variability of microbial species and physiological state of microorganisms [21]. Additionally, a relatively wide range of microorganisms in the raw milk are present and they can either be thermophilic, mesophilic or psychrophilic [7]. Therefore, the presence of more PEFresistant microorganisms [15] would reduce the effect of PEF processing.

In order to limit those variability effects, we made the choice during this study to 
a) $T_{\text {in }}=20^{\circ} \mathrm{C}$

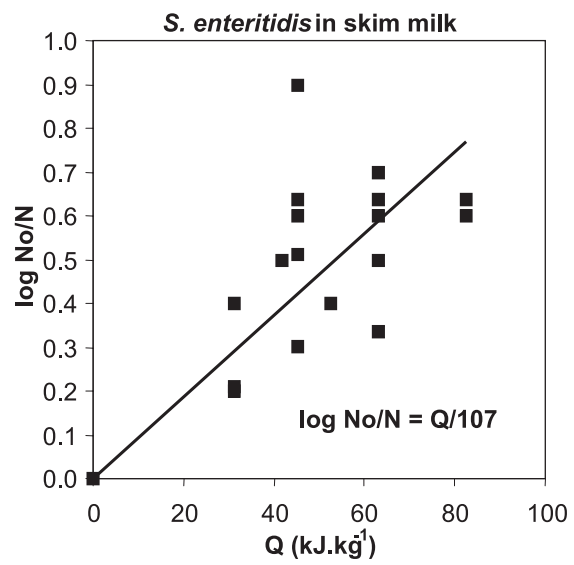

b) $T_{\text {in }}=20^{\circ} \mathrm{C}$

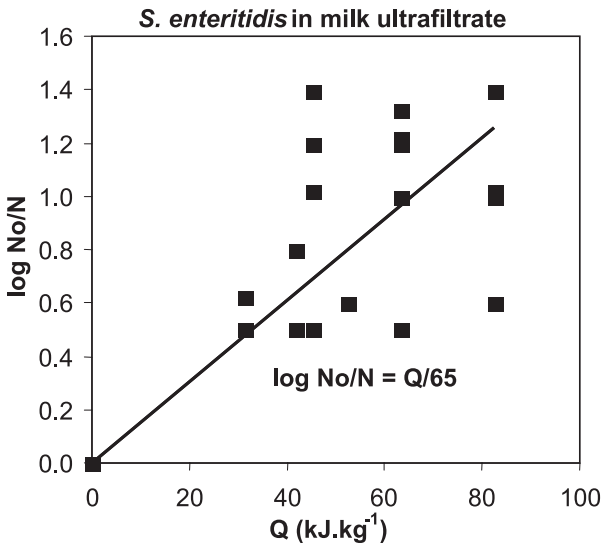

Figure 4. Decimal reduction number $\left(\log \mathrm{N}_{0} / \mathrm{N}\right)$ of Salmonella enteritidis population inoculated in (a) microfiltered skim milk and (b) milk ultrafiltrate, as a function of the amount of energy $(\mathrm{Q}$ in $\left.\mathrm{kJ} \cdot \mathrm{kg}^{-1}\right) \cdot \mathrm{T}_{\text {inlet }}=20^{\circ} \mathrm{C}$.

inoculate some microfiltered milk with a well-known microorganism, $S$. enteritidis, at a constant initial population value equal to $10^{7} \mathrm{cfu} \cdot \mathrm{mL}^{-1}$. These experiments allowed us to control the initial bacterial quality of the processed fluid better, and the constant initial population level and growth stage of the inoculated microorganisms. The PEF Salmonella enteritidis inactivation ratios obtained in these conditions were not better than those previously obtained on total raw skim milk microflora (Fig. 4a). One-log reduction was the maximum inactivation ratio obtained and results were still greatly variable. In that case, the decimal reduction energy, $\mathrm{Q}_{\mathrm{D}}$, was still about $110 \mathrm{~kJ} \cdot \mathrm{kg}^{-1}$, which was again much higher than the energy required to inactivate the same microorganism in the glucose and sulfate model solution [18].

According to Martin-Belloso et al. [19], inactivation of such microorganisms using PEF was more limited in skim milk than in a buffer solution when exposed to similar treatment conditions of field strength and number of pulses, because of the complex composition of skim milk and the presence of proteins.

$A Q_{D}$ value of $65 \mathrm{~kJ} \cdot \mathrm{kg}^{-1}$ was found for S. enteretidis in milk ultrafiltrate (UF) after
PEF treatments (Fig. 4b). However, and even if the absence of proteins in the medium had a positive effect on inactivation, this energy remained twice as high as the $\mathrm{Q}_{\mathrm{D}}$ obtained in the glucose and sulfate model solution [18]. Dutreux et al. [10] also reported less than 1-log difference between the inactivation of $E$. coli in milk and in phosphate buffer. Thus, the influence of the physicochemical composition of the medium on the microbial inactivation by $\mathrm{PEF}$ is still quite unclear, and there is a great need for further research in this field.

\subsection{Effect of PEF on milk components}

The effect of PEF treatments on physicochemical characteristics of milk and rennet coagulation was investigated.

\subsubsection{Viscosity and $\mathrm{pH}$}

The effect of the PEF treatment on the $\mathrm{pH}$ of milk was evaluated, but no change was noticed regardless of the energy level applied. It was equal to $6.72 \pm 0.03$ regardless of the PEF processing parameters applied. It is also of great interest to evaluate the effect of such treatment on the texture 


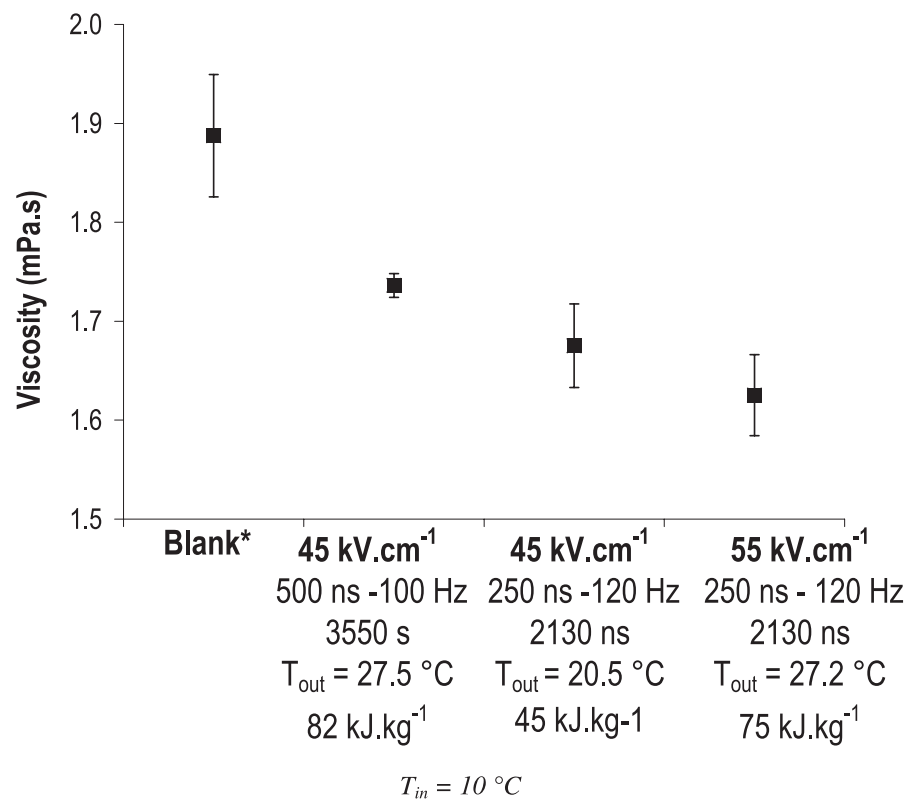

Figure 5. Comparison between the viscosity $\left(25^{\circ} \mathrm{C}\right)$ of initial raw skim milk and PEF-treated milk samples with different processing parameters. (* set of measurements significantly different from the others). $\mathrm{T}_{\text {inlet }}=10^{\circ} \mathrm{C}$.

of the product. As shown in Figure 5, experimental measurements showed a significant decrease in the viscosity of treated samples as compared with the initial raw skim milk $(P$-value $<0.05)$. We can suppose that modifications of the hydrodynamic volume of casein micelles or of the mineral balance may be involved, because they both have great influence on molecular interactions and aggregation states.

\subsubsection{Rennetability measurements}

The effect of PEF on the clotting time $(\mathrm{R})$, and the firmness of the gel (A2R) was studied using two different processing conditions: electric field equal to 45 or $55 \mathrm{kV} \cdot \mathrm{cm}^{-1}$, and pulse width equal to 250 or $500 \mathrm{~ns}$. In both cases (Fig. 6a, 6b), and even if reproducible experiments were difficult to manage with the Formagraph, clotting time showed a decreasing tendency (not significant), that was more marked when testing the effect of the electric field. However, only the coagulation parameters of the blank (untreated milk) were significantly different $(P$-value $<0.05)$ from the other sets of measurements (obtained with PEF-treated milk). The same observation has been previously reported by DesobryBanon et al. [8] when studying rennet coagulation of high-pressurized milk. The authors suggested that the decreased clotting time was related to a reduction in casein micelle size, leading to increased specific area and increased probability of interparticle collision [8].

Concerning the curd firmness of renneted milk, it was observed that the A2R parameters increased from $35( \pm 1) \mathrm{mm}$ for untreated milk to $39( \pm 1)$ and $40( \pm 1) \mathrm{mm}$ for PEF-treated milk with the following processing parameters: $55 \mathrm{kV} \cdot \mathrm{cm}^{-1} ; 250 \mathrm{~ns}$; $120 \mathrm{~Hz}$ and $45 \mathrm{kV} \cdot \mathrm{cm}^{-1}$; $500 \mathrm{~ns} ; 120 \mathrm{~Hz}$, corresponding to the highest energy level $\left(\mathrm{Q} \approx 100 \mathrm{~kJ} \cdot \mathrm{kg}^{-1}\right)$. Compared with highpressure treatments, an increase in gel firmness was also observed for milk treated for $10 \mathrm{~min}$ at $200 \mathrm{MPa}$. 

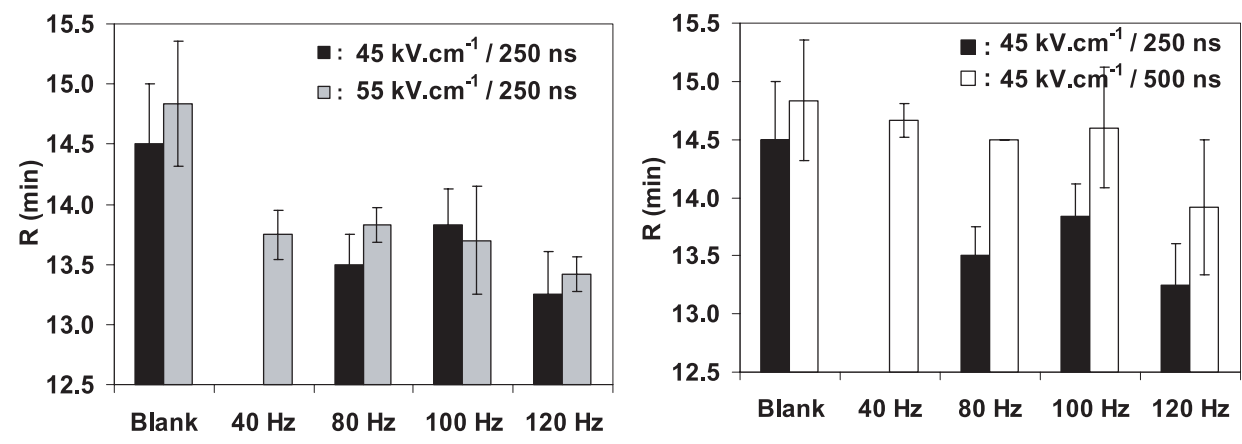

a)

$$
T_{\text {in }}=10^{\circ} \mathrm{C}
$$

b)

$$
T_{\text {in }}=10^{\circ} \mathrm{C}
$$

Figure 6. Evolution of the clotting time ( $\mathrm{R}$ in min) of PEF-treated skim milk samples in function of pulse frequencies. Two different processing conditions were tested: (a) effect of the electric fields and (b) effect of the pulse width. $\mathrm{T}_{\text {inlet }}=10^{\circ} \mathrm{C}$.

\subsubsection{Casein micelles characteristics}

In order to explain the evolution of texture and cheese-making properties of milk following PEF treatments, it was firstly considered whether the mineral balance of milk was not changed after exposure to strong electrical fields. Effects of PEF on minerals in milk can be divided into: the effects on the distribution between the colloidal and diffusible phases, and the effects on ionization. However, our measurements did not reveal any modification in the micellar mineral partition: the colloidal calcium fraction remained equal to $70( \pm 1) \%$ of the total calcium concentration regardless of the PEF processing parameters applied.

Figure 7 presents casein micelle average diameters versus PEF energy levels. A significant decrease $(P$-value $<0.05)$ in the casein micelle sizes following high field level PEF treatments $\left(45-55 \mathrm{kV} \cdot \mathrm{cm}^{-1}\right.$ with 2.1-3.5 $\mu$ s cumulated treatment time) can be observed. This diminution of the hydrodynamic volume of the micelles was hypothesized to be probably due to modification of the apparent charge after exposure to intense electrical fields and then modification of the ionic interactions between the caseins.

It is known that milks containing casein micelles of reduced diameter are less viscous and that milk coagulation properties are enhanced. When considering the curd firmness increase with the decreases in the clotting time such PEF treatments cause, this suggests acceleration of the aggregation phase of rennet coagulation in PEFprocessed milk and then intensification of molecular and/or micellar interactions. It can therefore be concluded that PEF processing of milk may involve modifications of its structure because functional properties such as cheese-making properties are modified by the treatment. These results are not in agreement with some other studies reporting that PEF treatment preserves the nutritional components and minimizes physical and chemical changes in food products [9, 14, 24]. Michalac et al. [21] measured that total solids, protein, $\mathrm{pH}$, electrical conductivity, viscosity and density of milk were not affected by PEF processing. Color and particle sizes of the milk were not changed significantly by this processing. Only Grahl and Märkl [14] measured some PEF-induced destruction of milk components, but only at high energy inputs $\left(\mathrm{Q}>200 \mathrm{~kJ} \cdot \mathrm{kg}^{-1}\right)$ for the enzyme lipase and vitamin $\mathrm{C}$ (ascorbic acid). Other food components that were analyzed (alkaline phosphatase, peroxidase, vitamin A and whey protein) did not show any large-scale inactivation. 


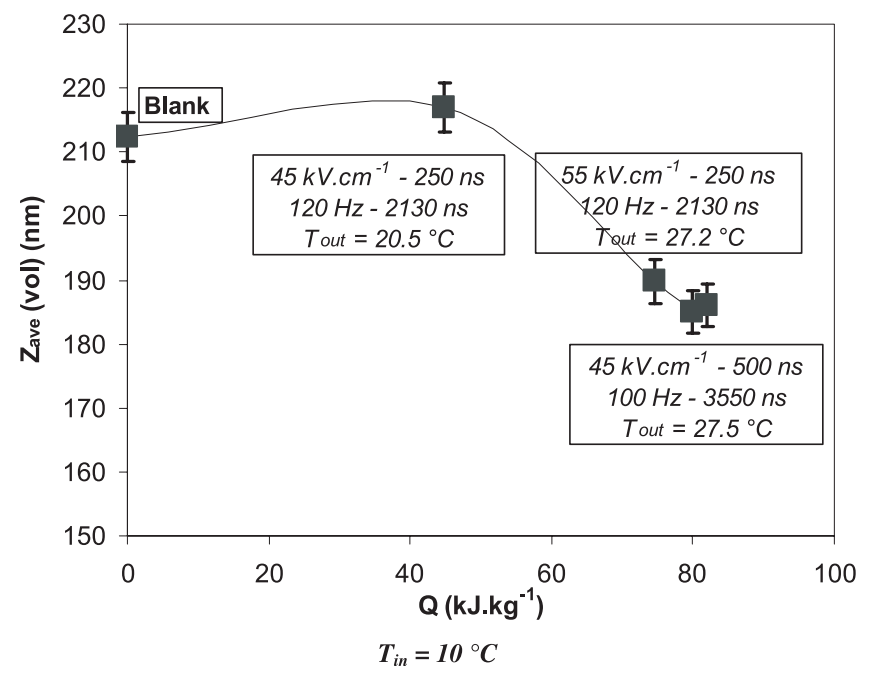

Figure 7. Casein micelle average diameters $\left(Z_{\text {ave }}\right.$ in $\left.\mathrm{nm}\right)$ versus $P E F$ energy levels $\left(\mathrm{Q}\right.$ in $\left.\mathrm{kJ}^{\mathrm{kg}} \mathrm{kg}^{-1}\right)$ measured by photon correlation spectroscopy.

\section{CONCLUSION}

The objective of this experimental work was to study the effectiveness of continuous PEF equipment (square wave pulses) on total microorganisms of milk and on S. enteritidis inactivation under moderate temperature $\left(\mathrm{T}<50{ }^{\circ} \mathrm{C}\right)$. With the chosen processing parameters that correspond to an energy input range of $0-100 \mathrm{~kJ} \cdot \mathrm{kg}^{-1}$, the effectiveness of PEF processing on microbial inactivation was very limited: $1.4-\log$ reduction of total microflora and $S$. enteritidis was the maximal inactivation ratio obtained. The effect of these PEF treatments on physicochemical and technological properties of the milk was also evaluated. These process conditions affected proteinic components of milk such as casein micelles, since the viscosity of PEF-treated milk decreased and coagulation properties were enhanced for high field levels (45$55 \mathrm{kV} \cdot \mathrm{cm}^{-1}$ ) with 2.1 to $3.5 \mu$ s cumulated treatment time and square waves. The results of other teams on the same topic did not show significant differences in micelle behavior after PEF treatment at a lower field level $\left(25-35 \mathrm{kV} \cdot \mathrm{cm}^{-1}\right)$. In the light of these results and some previous results reported in the literature, we can thus confirm that PEF treatments of milk at nonlethal temperatures do not constitute in themselves an alternative to heat treatments in the case of milk. Moreover, this study clearly revealed that, contrary to numerous previous studies, PEF treatments had an impact on some food constituents.

\section{REFERENCES}

[1] Barsotti L., Dumay E., Mu T.H., Diaz M.D.F., Cheftel J.-C., Effects of high voltage electric pulses on protein-based food constituents and structures, Trends Food Sci. Technol. 12 (2002) 136-144.

[2] Bendicho S., Barbosa-Canovas G.V., Martin O., Milk processing by high intensity pulsed electric fields, Trends Food Sci. Technol. 13 (2002) 195-204.

[3] Bendicho S., Barbosa-Canovas G.V., Martin O., Reduction of protease activity in simulated milk ultrafiltrate by continous flow high intensity pulsed electric field treatments, J. Food Sci. 68 (2003) 952-957.

[4] Brulé G., Maubois J.L., Fauquant J., Étude de la teneur en éléments minéraux des produits obtenus lors de l'ultrafiltration du lait sur membrane, Lait 54 (1974) 600-615. 
[5] Calderon-Miranda M.L., Barbosa-Canovas G.V., Swanson B.G., Inactivation of Listeria innocua in skim milk by pulsed electric fields and nisin, Int. J. Food Microbiol. 51 (1999) 19-30.

[6] Coster H.G.L., Zimmermann U., The mechanism of electrical breakdown in the membranes of Valonia utricularis, J. Membrane Biol. 22 (1975) 73-90.

[7] Cousin M.A., Presence and activity of psychrotrophic microorganisms in milk and dairy products: a review, J. Food Prot. 45 (1982) 172-207.

[8] Desobry-Banon S., Richard F., Hardy J., Study acid and rennet coagulation of high pressurized milk, J. Dairy Sci. 77 (1994) 3267-3274.

[9] Dunn J.E., Pearlman J.S., Methods and apparatus for extending the shelf-life of fluid food products, US Patent $n^{\circ} 4$ 695-472, 1987.

[10] Dutreux N., Notermans S., Wijtes T., GongoraNieto M.M., Barbosa-Canovas G.V., Swanson B.G., Pulsed electric fields inactivation of attached and free-living Escherichia coli and Listeria innocua under several conditions, Int. J. Food Microbiol. 54 (2000) 91-98.

[11] Evrendilek G.A., Zhang Q.H., Richter E.R., Application of pulsed electric fields to skim milk inoculated with Staphylococcus aureus, Biosyst. Eng. 87 (2004) 137-144.

[12] Fernandez-Molina J.J., Inactivation of Listeria innocua and Pseudomonas fluorescens in skim milk treated with pulsed electric fields, in: Barbosa-Canovas G.V., Zhang Q.H. (Eds.), Pulsed electric fields in food processing, fundamental aspects and applications, Technomic Publishing Company Inc., Lancaster, PA, USA, 2001, pp. 149-166.

[13] Fleischman G.J., Ravishankar S., Balasubramaniam V.M., The inactivation of Listeria monocytogenes by pulsed electric field (PEF) treatment in a static chamber, Food Microbiol. 21 (2004) 91-95.

[14] Grahl T., Märkl H., Killing of microorganisms by pulsed electric fields, Appl. Microbiol. Biotechnol. 45 (1996) 148-157.

[15] Hamilton W.A., Sale J.H., Effects of high electric fields on microorganisms. II. Mechanism of action at lethal effect, Biochem. Biophys. Acta. 14 (1967) 789-800.

[16] Heinz V., Alvarez I., Angersbach A., Knorr D., Preservation of liquid foods by high intensity pulsed electric fields - basic concepts for process design, Trends Food Sci. Technol. 12 (2002) 103-111.

[17] Jeantet R., Carballeira Fernández J.A., Roignant M., Cochet M.F., Baron F., Korolczuk J., Brion J.C., Performances d'un nouvel appareil de décontamination microbienne de produits liquides en continu par champs électriques pulsés, Ind. Aliment. Agric. 4 (2003) 9-14.

[18] Korolczuk J., Ripoll Mc Keag J., Carballeira Fernández J., Baron F., Grosset N., Jeantet R., Effect of pulsed electric field processing parameters on Salmonella enteritidis inactivation, J. Food Eng. (doi: 10.1016/j.jfoodeng.2005.03.027) (In press).

[19] Martin-Belloso O., Qin B.L., Chang F.J., Barbosa-Canovas G.V., Swanson B.G., Inactivation of Escherichia coli in skim milk by high intensity pulsed electric fields, J. Food Proc. Eng. 20 (1997) 317-336.

[20] McMahon D.J., Brown R.J., Evaluation of Formagraph for comparing rennet solutions, J. Dairy Sci. 65 (1982) 1639-1642.

[21] Michalac S., Alvarez V., Ji T., Zhang Q.H., Inactivation of selected microorganisms and properties of pulsed electric field processed milk, J. Food Proc. Preserv. 27 (2003) 137-151.

[22] Picart L., Dumay E., Cheftel J.-C., Inactivation of Listeria innocua in dairy fluids by pulsed electric fields: influence of electric parameters and food composition, Innov. Food Sci. Emerg. Technol. 3 (2002) 357-369.

[23] Pothakamury U.R., Monsalve-Gonzalez A., Barbosa-Canovas G.V., Swanson B.G., High voltage pulsed electric field inactivation of Bacillus subtilis and Lactobacillus delbrueckii, Rev. Espan. Cienc. Tecnol. Aliment. 35 (1995) 101-107.

[24] Qiu X., Sharma S., Tuhela L., Lia M., Zhang Q.H., An integrated PEF pilot plant for continuous nonthermal pasteurization of fresh orange juice, Transactions of the ASAE 41 (1998) 1069-1074.

[25] Raso J., Gongora M., Calderon M.L., BarbosaCanovas G.V., Swanson B.G., Pasteurization of raw skim milk by high intensity pulsed electric fields, in: 5th IFT Annual Meeting, Atlanta, GA, USA, 1998, p. 208.

[26] Reina L.D., Jin Z.T., Zhang Q.H., Yousef A.E., Inactivation of Listeria monocytogenes in milk by pulsed electric fields, J. Food Prot. 61 (1998) 1203-1206.

[27] Sensoy I., Zhang Q.H., Sastry S.K., Inactivation kinetic of Salmonella dublin by pulsed electric fields, J. Food Proc. Eng. 20 (1997) 367-381.

[28] Smith K., Mittal G.S., Griffiths M.W., Pasteurization of milk using pulsed electrical field and antimicrobials, J. Food Sci. 67 (2002) 2304-2308.

[29] Zannoni M., Annibaldi S., Standardization of the renneting ability of milk by formagraph, Sci.Tec. Latt. - Casearia 32 (1981) 79-94. 